\title{
IMÁGENES LATINOAMERICANAS
}

\section{(Editorial)}

Las imágenes forman parte de lo que los pobres mortales se inventan para registrar sus temblores (de deseo o de temor) y sus propias consumaciones.

Didi-Huberman, 2007

Este número de la Revista SulAmericana de Filosofia e Educação es lanzado en un momento en que nuestra región se ve especialmente convulsionada.

Nos llegan imágenes que nos muestran la alegría de los que despiertan pidiendo un orden más igualitario y aparecen bailando y cantando en las calles mezcladas con otras que nos enrostran la violencia de los que intentan expulsarlos, acallarlos, sacarlos de allí para que no se vean. Nos llegan imágenes de la furia de aquellos que no soportan que cuerpos que hablan el idioma de los originarios de estas tierras sean elegidos para ocupar espacios institucionales de jerarquía y, desde ellos, distribuyan lo que les pertenece a todos. Básicamente, cuerpos golpeados, castigados con agua, gases, palos; cuerpos huyendo ante la represión de los que están dispuestos a la eliminación del otro.

¿Cómo pensar esas imágenes?
Inspirado en Walter Benjamin, Didi-Huberman (2010, p. 171) nos invita a considerar en la dimensión crítica de la imagen.

Por una parte, perturba el curso normal del río (he ahí su aspecto de catástrofe, en el sentido morfológico del término) y, por otra, hace resurgir cuerpos olvidados por el río o por el glaciar más arriba, cuerpos que él 'restituye', hace aparecer, vuelve visibles de repente, pero momentáneamente: he ahí su aspecto de choque y de formación (...).

Las imágenes que nos llegan de Nuestra América reclaman una acogida crítica, que pueda sentir su catástrofe y que, al mismo tiempo, permita el resurgimiento de lo que se creía olvidado, "vuelva visibles" a aquellos que se intenta borrar.

La fuerza de esas imágenes - capturadas por fotógrafos y camarógrafos profesionales o por los celulares de los protagonistas - nos muestra, como nos enseñó Rancière (2014), cómo la estética está en la base de la política, dado que nuestro mundo se pone en juego en lo que permite ver y en lo que oculta a la mirada, en la configuración móvil de visibilidades e invisibilidades que deja en evidencia cómo se reparte lo sensible.

OLARIETA, Beatriz Fabiana. Imágenes latino-americanas (editorial). Revista Sul-Americana de Filosofia e Educação. Número 30: nov./2018-abr.2019, $\quad$ p. $1-3$. https://doi.org/10.26512/resafe.vi3o.28234 
Ese modo de reparto de lo sensible es estético y al mismo tiempo político, pues se constituye a partir de un determinado régimen de distribución dentro de lo común. Ese reparto dirá a quiénes les corresponde tomar parte de lo común y a quiénes no, a quiénes les corresponde ser visibles y a quiénes les corresponden ojos ciegos, que no los ven; quiénes tienen derecho a la palabra y para quiénes los oídos deben hacerse sordos. No es otra cosa que el modo en que se produce ese reparto de lo sensible lo que está en juego en la política como una forma de experiencia.

Hoy, América Latina está pidiendo atención precisamente para las formas de distribución dentro de este espacio y este tiempo comunes; está pidiendo desarmonizar las formas de reparto que volvieron invisibles a las grandes mayorías. Al mismo tiempo, está necesitando que se protejan las nuevas formas de distribución que fueron inventadas en nuestro continente para que aquellos que no tenían voz autorizada en el espacio común pasaran a tenerla, mostrándole al mundo formas más igualitarias de estar juntos.

Paulo Freire nos enseño que el trabajo de la educación consiste precisamente en posibilitarnos una lectura del mundo, un espacio donde podamos pensar nuestra forma de estar juntos en él. Para él la educación implica “(...) un constante acto de desvelamiento de la realidad" (FREIRE, 2014, p. 97) y, por tanto, un ejercicio sobre lo que vemos y sobre cómo vemos.

Hay algo que "nos mira en lo que vemos", afirma Didi-Huberman (2010). Y en esas imágenes es posible sentirlo. Hay allí algo que interrumpe las visiones cómodamente instaladas, algo de lo que no podemos dar cuenta fácilmente y que, sin embargo, está allí, mirándonos.

En las imágenes que nos llegan, Latinoamérica nos mira a partir de aquello que hace aparecer, que vuelve visible y que nos obliga a repensar nuestra forma de estar juntos en esta parte del mundo. Sentimos nuestra mirada interpelada por esas imágenes. Hay algo en ellas que demanda un trabajo sobre nuestra forma de ver, un trabajo que es, necesariamente, político y educativo.

Hoy, América Latina nos mira y abre en nuestra forma de ver una urgencia.

Beatriz Fabiana Olarieta Coeditora Revista Sul-Americana de Filosofia e Educação 


\section{Referências}

DIDI-HUBERMAN, Georges. O que vemos, o que nos olha. $2^{\circ}$ ed. São Paulo: 34, 2010. Cuando las imágenes tocan lo real. Conferencia realizada en el Museo de Arte Contemporáneo de Barcelona (MACBA), 2007. Disponible en: https://www.macba.cat/uploads/20080408/Georges Didi Huberman Cuando las imagene s tocan lo real.pdf

FREIRE, Paulo. Pedagogia do oprimido. Rio de Janeiro: Paz y Terra, 2014.

RANCIÈRE, Jacques. El reparto de lo sensible. Estética y política. Buenos Aires: Promete, 2014 . 